\title{
Hymenobacter soli sp. nov., isolated from grass soil
}

Correspondence

Sung-Taik Lee

e_stlee@kaist.ac.kr

\author{
Kyoung-Ho Kim,† Wan-Taek Im and Sung-Taik Lee
}

Department of Biological Sciences, Korea Advanced Institute of Science and Technology, 373-1, Guseong-dong, Yuseong-gu, Daejeon 305-701, Republic of Korea

\begin{abstract}
A Gram-negative, strictly aerobic, non-spore-forming, rod-shaped, red-pink bacterium, designated strain $\mathrm{PB} 17^{\top}$, was isolated from grass soil in the Republic of Korea and its taxonomic position was investigated by means of a polyphasic approach. Phylogenetic analysis of 16S rRNA gene sequences showed that strain $\mathrm{PB} 17^{\top}$ belonged to the genus Hymenobacter. Sequence similarities between strain PB17 $7^{\top}$ and the type strains of Hymenobacter species with validly published names ranged from 90.1 to $91.8 \%$. The predominant cellular fatty acids in strain PB1 $7^{\top}$ were iso- $\mathrm{C}_{15: 0}$, summed feature 4 (iso- $\mathrm{C}_{15: 0} 2-\mathrm{OH}$ and/or $\mathrm{C}_{16: 1} \omega 7 c$ ), $\mathrm{C}_{16: 1} \omega 5 c$ and anteiso- $\mathrm{C}_{15: 0}$. The DNA G+C content was $58.8 \mathrm{~mol} \%$. The results of phylogenetic, chemotaxonomic and phenotypic characterization indicated that strain $\mathrm{PB} 17^{\top}$ can be distinguished from all known Hymenobacter species and represents a novel species, for which the name Hymenobacter soli sp. nov. is proposed. The type strain is PB17 ${ }^{\top}$ (=KCTC $12607^{\top}$ $=$ LMG $24240^{\top}$ ).
\end{abstract}

Hirsch et al. (1998) proposed a novel genus and species, Hymenobacter roseosalivarius, by describing five strains isolated from Antarctic soil. Hymenobacter actinosclerus (a radiation-resistant bacterium isolated from irradiated pork) and Hymenobacter aerophilus (isolated from air) were subsequently added to the genus (Collins et al., 2000; Buczolits et al., 2002). Recently, four more species were proposed: Hymenobacter norwichensis, $H$. ocellatus, $H$. gelipurpurascens and $H$. chitinivorans (Buczolits et al., 2006). The members of the genus Hymenobacter have high $\mathrm{G}+\mathrm{C}$ contents $(55-65 \mathrm{~mol} \%)$ compared with other members of the family 'Flexibacteraceae' in the class 'Sphingobacteria' (Garrity \& Holt, 2001) (27-48 mol\%) (Buczolits et al., 2002).

During the course of a study on culturable, aerobic, pigmented bacterial strains from soil and a stream in Daejeon, Republic of Korea, a large number of novel bacterial strains were isolated. One of these isolates, strain $\mathrm{PB} 17^{\mathrm{T}}$, was found to be a member of the genus Hymenobacter in the phylum Bacteroidetes and was subjected to further taxonomic investigation. In this study, we analysed its genotypic, chemotaxonomic and phenotypic characteristics in order to establish its phylogenetic affiliation.

Strain $\mathrm{PB} 17^{\mathrm{T}}$ was isolated from grass soil in April 2004. The soil sample was thoroughly suspended in $50 \mathrm{mM}$

†Present address: Biological Resource Center, Korea Research Institute of Bioscience and Biotechnology, 52 Oeundong, Yusong-gu, Daejeon 305-333, Republic of Korea.

The GenBank/EMBL/DDBJ accession number for the 16S rRNA gene sequence of strain $\mathrm{PB} 17^{\top}$ is $\mathrm{AB} 251884$. phosphate buffer ( $\mathrm{pH} 7.0)$ and the suspension was spread on R2A agar (Scharlau). After incubation at $25{ }^{\circ} \mathrm{C}$ for 1 or 2 weeks, the pigmented colonies that formed were picked and subcultured several times to confirm that they were pure cultures. Isolates were routinely cultured on R2A agar at $30{ }^{\circ} \mathrm{C}$ and maintained as glycerol suspensions $(20 \%$, $\mathrm{w} / \mathrm{v})$ at $-70{ }^{\circ} \mathrm{C}$.

The Gram reaction was performed using the non-staining method, as described previously (Buck, 1982). Cell morphology was examined by using light microscopy (E600; Nikon). Catalase activity was determined from bubble production in $3 \%(\mathrm{v} / \mathrm{v}) \mathrm{H}_{2} \mathrm{O}_{2}$ and oxidase activity was determined using $1 \%(\mathrm{w} / \mathrm{v})$ tetramethyl- $p$-phenylenediamine. Flexirubin-type pigments were detected by suspending cells in $20 \% \mathrm{KOH}$ (Fautz \& Reichenbach, 1980). Enzyme activities, substrates that could be utilized as sole carbon sources and some physiological characteristics were determined with API ZYM, API 20E, API $50 \mathrm{CH}$ and API 20NE galleries according to the instructions of the manufacturer (bioMérieux). The defined liquid mineral salts medium used for the API $50 \mathrm{CH}$ and API 20NE tests contained $\left(\mathrm{l}^{-1}\right)$ : $1.8 \mathrm{~g} \mathrm{~K} \mathrm{~K}_{2} \mathrm{HPO}_{4}, 1.08 \mathrm{~g} \mathrm{KH}_{2} \mathrm{PO}_{4}, 0.5 \mathrm{~g}$ $\mathrm{NaNO}_{3}, 0.5 \mathrm{~g} \mathrm{NH}_{4} \mathrm{Cl}, 0.1 \mathrm{~g} \mathrm{KCl}, 0.1 \mathrm{~g} \mathrm{MgSO}_{4}$ and $0.05 \mathrm{~g}$ $\mathrm{CaCl}_{2}$, supplemented with vitamin solution (Widdel \& Bak, 1992), trace element solution SL-10 (Widdel et al., 1983) and selenite/tungstate solution (Tschech \& Pfennig, 1984). The $\mathrm{pH}$ of the medium was adjusted to 6.8. A test for anaerobic growth was performed in a serum bottle containing R2A broth supplemented with sodium thioglycolate $\left(1 \mathrm{~g} \mathrm{l}^{-1}\right)$ and the gas phase was replaced with nitrogen gas. A nitrate-reduction test was performed in a serum bottle containing R2A broth supplemented with $\mathrm{KNO}_{3}(10 \mathrm{mM})$ and the reduction of nitrate was 
Table 1. Differential characteristics of strain PB1 $7^{\top}$ and members of the genus Hymenobacter

Strains: 1, PB17 ${ }^{\mathrm{T}}$; 2, H. ocellatus Myx2105 ${ }^{\mathrm{T}}$; 3, H. roseosalivarius DSM $11622^{\mathrm{T}} ; 4$, H. aerophilus $\mathrm{I} / 26-\mathrm{Cor}^{\mathrm{T}}$; 5, H. actinosclerus CCUG $39621^{\mathrm{T}}$; 6 , H. chitinivorans $\operatorname{Txc1}^{\mathrm{T}} ; 7$, H. gelipurpurascens $\operatorname{Txg} 1^{\mathrm{T}} ; 8$, H. norwichensis DSM 15439 ${ }^{\mathrm{T}}$; 9, Hymenobacter sp. DSM 15438. Data for reference strains are from Hirsch et al. (1998), Collins et al. (2000) and Buczolits et al. (2002, 2006). All of the strains are negative for assimilation of L-arabinose, Dadonitol, inositol, D-sorbitol, phenylacetate and L-rhamnose and for indole production. +, Positive; -, negative; (+), weakly positive; ND, no data available.

\begin{tabular}{|c|c|c|c|c|c|c|c|c|c|}
\hline Characteristic & 1 & 2 & 3 & 4 & 5 & 6 & 7 & 8 & 9 \\
\hline \multicolumn{10}{|l|}{ Growth at/in: } \\
\hline $1 \% \mathrm{NaCl}$ & - & + & + & + & ND & $(+)$ & $(+)$ & - & - \\
\hline $3 \% \mathrm{NaCl}$ & - & + & ND & $(+)$ & $\mathrm{ND}$ & $(+)$ & $(+)$ & - & - \\
\hline $4^{\circ} \mathrm{C}$ & + & $-*$ & + & + & - & + & $(+)$ & $(+)$ & - \\
\hline $37^{\circ} \mathrm{C}$ & - & + & - & - & + & - & - & - & - \\
\hline \multicolumn{10}{|l|}{ Assimilation of: } \\
\hline Arbutin & + & - & - & - & $(+)$ & - & - & $(+)$ & - \\
\hline D-Galactose & + & - & - & - & - & - & - & $(+)$ & - \\
\hline D-Mannose & + & - & - & $(+)$ & $(+)$ & - & - & $(+)$ & - \\
\hline D-Ribose & $(+)$ & - & - & - & $(+)$ & - & - & $(+)$ & - \\
\hline D-Glucose & - & - & - & $(+)$ & $(+)$ & - & - & $(+)$ & - \\
\hline D-Fructose & - & - & - & $(+)$ & - & - & - & $(+)$ & - \\
\hline Cellobiose & - & - & - & - & $(+)$ & - & - & $(+)$ & - \\
\hline $\begin{array}{l}N \text {-Acetyl-D-glucosamine, } \\
\text { gluconate }\end{array}$ & - & - & - & - & $(+)$ & - & - & - & - \\
\hline $\begin{array}{l}\text { D-Xylose, salicin, maltose, } \\
\text { trehalose, D-mannitol }\end{array}$ & - & - & - & - & - & - & - & $(+)$ & - \\
\hline Sucrose & - & - & - & $(+)$ & - & - & - & - & - \\
\hline Adipate, citrate & - & - & - & - & $(+)$ & - & - & - & - \\
\hline Arginine dihydrolase & + & - & ND & - & $\mathrm{ND}$ & - & - & - & - \\
\hline Urease & + & - & ND & - & - & - & - & - & - \\
\hline \multicolumn{10}{|l|}{ Enzyme activities (API ZYM) } \\
\hline Alkaline phosphatase & + & + & $\mathrm{ND}$ & + & + & + & + & + & + \\
\hline Leucine arylamidase & + & $(+)$ & $\mathrm{ND}$ & + & + & + & + & + & + \\
\hline Cystine arylamidase & + & - & $\mathrm{ND}$ & - & + & - & - & - & + \\
\hline Valine arylamidase & + & - & $\mathrm{ND}$ & + & + & - & $(+)$ & $(+)$ & + \\
\hline $\begin{array}{l}\text { Naphthol-AS-BI- } \\
\text { phosphohydrolase }\end{array}$ & + & $(+)$ & $\mathrm{ND}$ & + & $\mathrm{ND}$ & $(+)$ & $(+)$ & + & + \\
\hline Esterase (C4) & + & - & ND & + & ND & $(+)$ & $(+)$ & $(+)$ & + \\
\hline Esterase lipase (C8) & + & $(+)$ & $\mathrm{ND}$ & + & + & $(+)$ & $(+)$ & $(+)$ & + \\
\hline$\alpha$-Galactosidase & $(+)$ & - & + & - & - & - & - & - & + \\
\hline$\beta$-Galactosidase & + & - & ND & - & - & - & - & - & - \\
\hline $\begin{array}{l}\beta \text {-Glucuronidase, lipase (C14), } \\
\alpha \text {-mannosidase, } \alpha \text {-fucosidase, } \\
\text { chymotrypsin, trypsin }\end{array}$ & - & - & ND & - & - & - & - & - & - \\
\hline$\alpha$-Glucosidase & + & - & + & - & $\mathrm{ND}$ & - & - & - & - \\
\hline$\beta$-Glucosidase & $(+)$ & - & + & - & - & - & - & $(+)$ & - \\
\hline$N$-Acetyl- $\beta$-glucosaminidase & $(+)$ & - & $\mathrm{ND}$ & - & + & - & - & - & - \\
\hline Acid phosphatase & + & - & ND & + & + & - & - & $(+)$ & + \\
\hline Media allowing growth $\dagger$ & $\mathrm{R} 2 \mathrm{~A}$ & $\begin{array}{r}\text { PYES, R2A, } \\
\text { C-D, TSA }\end{array}$ & $\begin{array}{r}\text { PYGV, } \\
\text { R2A }\end{array}$ & $\begin{array}{c}\text { PYES, R2A, } \\
\text { TSA }\end{array}$ & $\begin{array}{l}\text { YB agar, } \\
\text { TSA }\end{array}$ & $\begin{array}{r}\text { PYES, R2A, } \\
\text { C-D, TSA }\end{array}$ & $\begin{array}{r}\text { PYES, R2A, } \\
\text { C-D, TSA }\end{array}$ & $\begin{array}{r}\text { PYES, } \\
\text { R2A }\end{array}$ & PYES, R2A \\
\hline Media not allowing growth $\dagger$ & $\begin{array}{r}\text { TSA, } \\
\text { MC }\end{array}$ & $\mathrm{MC}$ & ND & $\mathrm{C}-\mathrm{D}, \mathrm{MC}$ & $\mathrm{ND}$ & $\mathrm{MC}$ & MC & $\begin{array}{c}\mathrm{TSA} \ddagger \\
\mathrm{C}-\mathrm{D}, \mathrm{MC}\end{array}$ & $\begin{array}{c}\mathrm{TSA} \neq \\
\mathrm{C}-\mathrm{D}, \mathrm{MC}\end{array}$ \\
\hline Source of isolation & Soil & Soil & Soil & Air & Pork & Soil & Soil & Air & Air \\
\hline DNA $\mathrm{G}+\mathrm{C}$ content $(\mathrm{mol} \%)$ & 58.8 & $\sim 65$ & 56 & 63.1 & 62 & 61 & $57-58$ & ND & ND \\
\hline
\end{tabular}

${ }^{*}$ No growth at $5{ }^{\circ} \mathrm{C}$ (Collins et al., 2000).

$\nmid$ C-D, Czapek-Dox agar; MC, MacConkey agar; PYES, PYES agar (Buczolits et al., 2002); PYGV, peptone-yeast extract-glucose-vitamins; TSA, trypticase soy agar; YB, yeast broth.

$\ddagger$ Poor growth on this medium. 
monitored using an ion chromatograph (model 790 personal IC; Metrohm) equipped with a conductivity detector and an anion exchange column (Metrosep Anion Supp 4; Metrohm). Growth at different temperatures $(4,15$,

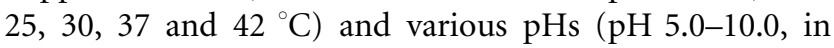
increments of $0.5 \mathrm{pH}$ units) was assessed after 5 days incubation. Salt tolerance was tested on R2A agar supplemented with $1-10 \%(\mathrm{w} / \mathrm{v}) \mathrm{NaCl}$ after 5 days incubation.

To measure the $\mathrm{G}+\mathrm{C}$ content of the chromosomal DNA, genomic DNA was extracted and purified as described by Ausubel et al. (1987) and was determined as described by Mesbah \& Whitman (1989) using reversed-phase HPLC. Isoprenoid quinones were extracted with chloroform/ methanol $(2: 1, \mathrm{v} / \mathrm{v})$, evaporated under a vacuum and then re-extracted in $n$-hexane-water $(1: 1, \mathrm{v} / \mathrm{v})$. The crude n-hexane-quinone solution was purified using Sep-Pak Vac Cartridges Silica (Waters) and subsequently analysed by HPLC, as described previously (Hiraishi et al., 1996). Cellular fatty acid profiles were determined for cells grown on R2A agar for 3 days at $28{ }^{\circ} \mathrm{C}$. The cellular fatty acids were saponified, methylated and extracted according to the protocol of the Sherlock Microbial Identification System (MIDI). The fatty acids were analysed with a gas chromatograph (model 6890; Hewlett Packard) and identified using the Microbial Identification software package (Sasser, 1990).

PCR-mediated amplification of the 16S rRNA gene and sequencing of the purified PCR product were carried out according to Kim et al. (2005). The complete $16 \mathrm{~S}$ rRNA gene sequence was compiled using SeqMan software (DNASTAR). Related sequences were obtained from the databases of Ribosomal Database Project II (Cole et al., 2005) and GenBank (Benson et al., 2005) and multiple alignment was done using the CLUSTAL_X program (Thompson et al., 1997). Some ambiguous sequences, gaps and $5^{\prime}$ and $3^{\prime}$ ends of the alignment were edited manually using the program BioEdit (Hall, 1999). The phylogenetic tree was constructed using the neighbour-joining method (Saitou \& Nei, 1987) within the program MEGA3 (Kumar et al., 2004), with bootstrap analysis based on 1000 resamplings (Felsenstein, 1985). Distance matrices were calculated using Kimura's two-parameter model (Kimura, 1983).

Cells of strain $\mathrm{PB} 17^{\mathrm{T}}$ were Gram-negative, non-motile, nonspore-forming and rod-shaped. Colonies grown on R2A agar for 3 days were circular, entire, smooth, red-pink, transparent and $0.5-2.0 \mathrm{~mm}$ in diameter. After about 57 days, colonies became mucoid and slimy; an extracellular polymer was produced, forming a thin, transparent layer around the colonies. Capsules were observed with cells that had been negatively stained with nigrosin. Cells became shorter and almost coccoid in the stationary growth phase. An extracellular polymer, a thin layer, a capsule and changes in cell size were also reported for $H$. roseosalivarius (Hirsch et al., 1998). Strain $\mathrm{PB} 17^{\mathrm{T}}$ could grow at $4-30{ }^{\circ} \mathrm{C}$ but did not grow at 37 or $42{ }^{\circ} \mathrm{C}$ on R2A agar. It could grow at $\mathrm{pH} 5.0-$ 8.5 but did not grow at $\mathrm{pH} 9.0$ or 10.0 . The presence of $1 \%$ $\mathrm{NaCl}$ or more inhibited growth. The strain could not grow under anaerobic or denitrifying conditions. Physiological characteristics of strain $\mathrm{PB}_{17}^{\mathrm{T}}$ are summarized in the species description. Selected characteristics that serve to differentiate strain $\mathrm{PB}_{17} 7^{\mathrm{T}}$ from related species of the genus Hymenobacter are shown in Table 1.

An almost-complete 16S rRNA gene sequence (1473 bp in length) was obtained for strain $\mathrm{PB} 17^{\mathrm{T}}$. Comparisons with corresponding sequences showed that strain $\mathrm{PB} 17^{\mathrm{T}}$ had the highest levels of similarity with respect to the following type strains: $H$. actinosclerus CCUG $39621^{\mathrm{T}}(91.8 \%), H$. chitinivorans $\mathrm{Txcl}^{\mathrm{T}}(91.7 \%), H$. aerophilus $\mathrm{I} / 26-\mathrm{Cor}^{\mathrm{T}}$ $(91.4 \%), H$. roseosalivarius DSM $11622^{\mathrm{T}}(91.2 \%), H$. gelipurpurascens $\operatorname{Txg}^{\mathrm{T}}$ (90.8\%), H. ocellatus Myx $2105^{\mathrm{T}}$ $(90.3 \%)$ and H. norwichensis DSM $15439^{\mathrm{T}}(90.1 \%)$.

In the neighbour-joining tree constructed using the $16 \mathrm{~S}$ rRNA gene sequences of the novel strain and strains of the genus Hymenobacter, $\mathrm{PB} 17^{\mathrm{T}}$ clustered within the radiation of the genus Hymenobacter but was separate from recognized Hymenobacter species. Its distinct phylogenetic position was supported by high bootstrap percentages

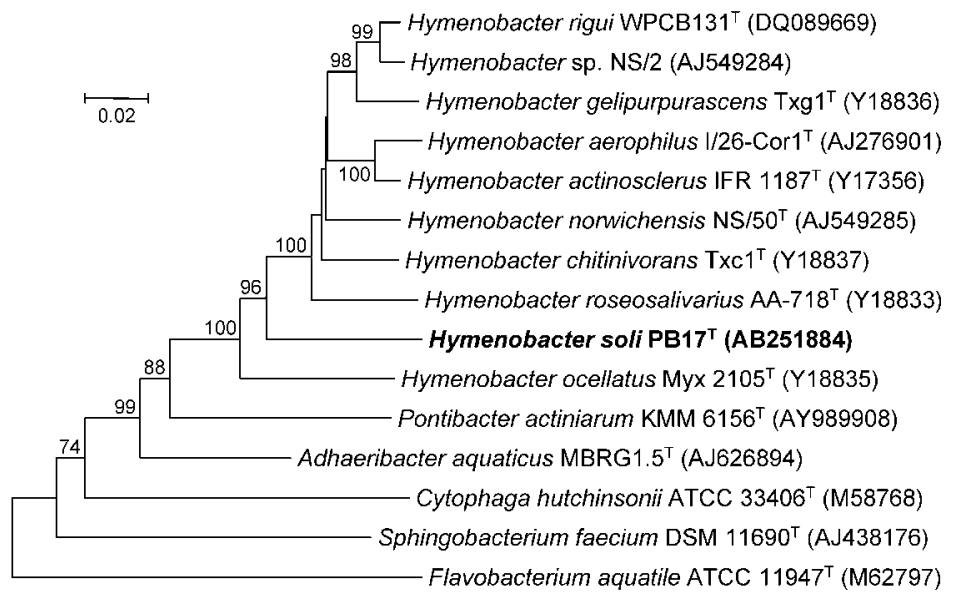

Fig. 1. Neighbour-joining phylogenetic tree, based on 16S rRNA gene sequences, for strain $\mathrm{PB} 17^{\top}$ and related species. Bootstrap percentages (based on 1000 replications) $>70 \%$ are shown at branch points. Bar, 2 substitutions per 100 nucleotide positions. 
(96-100\%) (Fig. 1). Low levels of similarity with respect to recognized Hymenobacter species (90.1-91.8\%) indicate that $\mathrm{PB} 17^{\mathrm{T}}$ represents a novel species.

The predominant isoprenoid quinone was determined as MK-7. The DNA G+C content of strain $\mathrm{PB}_{17}{ }^{\mathrm{T}}$ was 58.8 mol\%: such relatively high values are unique to the genus Hymenobacter, distinguishing it from other genera of the family 'Flexibacteraceae'.

The major cellular fatty acids of strain $\mathrm{PB} 17^{\mathrm{T}}$ were iso$\mathrm{C}_{15: 0}$, summed feature 4 (iso- $\mathrm{C}_{15: 0} \quad 2-\mathrm{OH}$ and/or $\left.\mathrm{C}_{16: 1} \omega 7 c / t\right), \mathrm{C}_{16: 1} \omega 5 c$ and anteiso- $\mathrm{C}_{15: 0}$. The profile of strain $\mathrm{PB} 17^{\mathrm{T}}$ was qualitatively similar to those of members of the genus Hymenobacter, but it showed quantitative differences, e.g. a large proportion of iso- $\mathrm{C}_{15: 0}$ and a small proportion of summed feature 5 (iso- $\mathrm{C}_{17: 1} \mathrm{I}$ and/or anteiso- $\mathrm{C}_{17: 1}$ B) (Table 2).

Morphological similarities, the relatively high DNA G $+C$ content and the phylogenetic data indicated that $\mathrm{PB} 17^{\mathrm{T}}$ belongs to the genus Hymenobacter. However, the low levels of $16 \mathrm{~S}$ rRNA gene sequence similarity (90.1-91.8\%) between $\mathrm{PB} 17^{\mathrm{T}}$ and members of the genus Hymenobacter, its quantitative fatty acid profile and its differential phenotypic characteristics supported the notion that strain $\mathrm{PB} 17^{\mathrm{T}}$ represents a novel species. On the basis of the data and observations described above, therefore, strain $\mathrm{PB} 17^{\mathrm{T}}$ represents a novel species of the genus Hymenobacter, for which the name Hymenobacter soli sp. nov. is proposed.

\section{Description of Hymenobacter soli sp. nov.}

Hymenobacter soli (so'li. L. neut. gen. n. soli of soil, the source of the type strain).

Cells are Gram-negative, rod-shaped, non-spore-forming and non-motile. Obligately aerobic, chemo-organotrophic. Cells are $0.6-1.0 \mu \mathrm{m}$ wide and $2.0-4.0 \mu \mathrm{m}$ long. Cells grow on R2A agar, but not on trypticase soy agar or MacConkey agar. Colonies on R2A agar are circular, entire, smooth, red-pink, transparent and slimy. Cells produce extracellular polymer and form thin, spreading layers around colonies on agar surfaces. A capsule is observed in negatively stained cells. Cells become shorter and almost coccoid in the stationary growth phase on R2A agar. No flexirubin-type pigments are formed. Oxidase- and catalase-positive. Grows at $4-30{ }^{\circ} \mathrm{C}$, but not at $37{ }^{\circ} \mathrm{C}$. The presence of more than $1 \% \mathrm{NaCl}$ inhibits growth on $\mathrm{R} 2 \mathrm{~A}$ agar. No growth occurs under anaerobic or denitrifying conditions. The DNA G + C content of the type strain is $58.8 \mathrm{~mol} \%$. The major respiratory quinone is MK-7. The major cellular fatty acids are iso- $\mathrm{C}_{15: 0}$, summed feature 4 (iso- $\mathrm{C}_{15: 0} 2-\mathrm{OH}$ and/or $\left.\mathrm{C}_{16: 1} \omega 7 c / t\right), \mathrm{C}_{16: 1} \omega 5 c$ and anteiso- $\mathrm{C}_{15: 0}$. Does not hydrolyse agar, xylan, cellulose, skimmed milk, chitin or olive oil. Arbutin, aesculin, Dgalactose, 5-ketogluconate and D-mannose are assimilated. Weakly positive for assimilation of glycerol and D-ribose. The following substrates are not assimilated: $N$-acetyl-Dglucosamine, D-adonitol, starch, amygdalin, D- and
Table 2. Cellular fatty acid profiles of strain $\mathrm{PB} 17^{\top}$ and its closest relatives

Strains: $1, \mathrm{~PB} 17^{\mathrm{T}}$ (data from this study); 2, H. ocellatus Myx $2105^{\mathrm{T}}$ (Buczolits et al., 2006); 3, H. roseosalivarius DSM $11622^{\mathrm{T}} ; 4, H$. aerophilus $\mathrm{I} / 26-\operatorname{Cor}^{\mathrm{T}}{ }^{\mathrm{T}}$; 5, H. actinosclerus CCUG $39621^{\mathrm{T}}$ (data in columns 3-5 from Buczolits et al., 2002); 6, H. chitinivorans $\operatorname{Txcl}^{\mathrm{T}} ; 7$, H. gelipurpurascens $\operatorname{Txg} 1^{\mathrm{T}} ; 8, H$. norwichensis DSM $15439^{\mathrm{T}} ; 9$, Hymenobacter sp. DSM 15438 (data in columns 6-9 from Buczolits et al., 2006). Culture conditions: strains 1 and 3 were grown on R2A for $72 \mathrm{~h}$ at $28{ }^{\circ} \mathrm{C}$; strains 2,6 and 7 were grown on TSA; strains 4 and 5 were grown on TSA for $72 \mathrm{~h}$ at $28{ }^{\circ} \mathrm{C}$; strains 8 and 9 were grown on PYES agar (Buczolits et al., 2002) at $25{ }^{\circ} \mathrm{C}$. Values are percentages of total fatty acids; -, not detected; ECL, equivalent chain length. Discriminative components are highlighted in bold.

\begin{tabular}{|c|c|c|c|c|c|c|c|c|c|}
\hline Fatty acid & 1 & 2 & 3 & 4 & 5 & 6 & 7 & 8 & 9 \\
\hline \multicolumn{10}{|l|}{ Saturated } \\
\hline $\mathrm{C}_{14: 0}$ & 1.2 & - & - & - & - & - & - & 1.3 & 0.3 \\
\hline $\mathrm{C}_{15: 0}$ & - & - & - & - & - & - & - & 0.5 & - \\
\hline $\mathrm{C}_{16: 0}$ & 4.2 & 0.6 & 1.1 & 1.7 & - & - & - & 2.2 & 1.0 \\
\hline \multicolumn{10}{|l|}{ Unsaturated } \\
\hline $\mathrm{C}_{15: 1} \omega 6 c$ & - & - & - & 0.8 & 0.8 & - & - & 0.5 & - \\
\hline $\mathrm{C}_{16: 1} \omega 5 c$ & 11.0 & 2.0 & 23.3 & 7.9 & 3.7 & 8.9 & 11.3 & 13.6 & 7.4 \\
\hline $\mathrm{C}_{16: 1} \omega 7 c$ alcohol & 0.5 & - & 0.7 & - & - & - & - & - & - \\
\hline $\mathrm{C}_{17: 1} \omega 6 c$ & - & 1.2 & 1.1 & - & 0.7 & - & - & - & 0.5 \\
\hline \multicolumn{10}{|l|}{ Branched-chain } \\
\hline $\begin{array}{l}\text { iso- } C_{13: 0} \\
\text { iso- } C_{14: 0}\end{array}$ & - & $\begin{array}{l}0.6 \\
1.5\end{array}$ & - & - & $\begin{array}{l}- \\
-\end{array}$ & $\begin{array}{l}0.6 \\
0.5\end{array}$ & - & $\begin{array}{l}- \\
0.8\end{array}$ & $\begin{array}{l}- \\
0.6\end{array}$ \\
\hline iso- $\mathrm{C}_{15: 0}$ & 51.8 & 36.7 & 8.3 & 10.8 & 22.3 & 31.1 & 17.3 & 27.3 & 18.7 \\
\hline iso- $\mathrm{C}_{15: 1} \mathrm{G}$ & - & - & - & - & - & 0.6 & 0.8 & - & - \\
\hline anteiso- $\mathrm{C}_{15: 0}$ & 6.2 & 3.9 & - & 22.3 & 25.8 & 3.7 & 23.1 & 10.6 & 16.2 \\
\hline anteiso- $C_{15: 1} \mathrm{~A}$ & - & - & - & - & - & - & 1.1 & - & 1.0 \\
\hline iso- $\mathrm{C}_{16: 0}$ & - & 2.9 & 2.1 & 0.8 & - & 1.4 & 2.7 & 1.2 & 1.3 \\
\hline iso- $\mathrm{C}_{16: 1} \mathrm{H}$ & 1.0 & 1.3 & 2.7 & 1.5 & 1.5 & 2.0 & 3.7 & 1.4 & 2.0 \\
\hline iso- $\mathrm{C}_{17: 0}$ & 1.1 & 2.8 & 1.7 & 4.5 & 1.8 & 2.6 & 1.7 & 1.6 & 2.0 \\
\hline iso- $\mathrm{C}_{17: 1} \omega 9 c$ & - & 0.6 & - & - & - & 0.7 & - & - & 0.5 \\
\hline anteiso- $\mathrm{C}_{17: 0}$ & - & - & - & 2.3 & 0.7 & - & 2.0 & - & 1.3 \\
\hline \multicolumn{10}{|c|}{ Hydroxy fatty acids } \\
\hline $\mathrm{C}_{15: 0} 2-\mathrm{OH}$ & - & - & - & - & - & - & 0.9 & - & 1.0 \\
\hline iso- $\mathrm{C}_{15: 0} 2-\mathrm{OH}$ & - & - & - & 0.9 & 0.8 & - & - & - & - \\
\hline iso- $\mathrm{C}_{15: 0} 3-\mathrm{OH}$ & 2.1 & 4.3 & 2.7 & 1.6 & 1.6 & 4.1 & 2.3 & 2.2 & 2.0 \\
\hline $\mathrm{C}_{16: 0} 3-\mathrm{OH}$ & 1.0 & - & 1.2 & - & - & 0.5 & - & 0.6 & 0.4 \\
\hline iso- $\mathrm{C}_{16: 0} 3-\mathrm{OH}$ & - & - & 1.0 & - & - & - & - & - & 0.3 \\
\hline $\mathrm{C}_{17: 0} 2-\mathrm{OH}$ & - & - & - & 1.3 & - & - & 1.7 & - & 1.0 \\
\hline iso- $\mathrm{C}_{17: 0} 2-\mathrm{OH}$ & - & - & - & - & 2.0 & - & - & - & - \\
\hline iso- $\mathrm{C}_{17: 0} 3-\mathrm{OH}$ & 1.2 & 6.8 & 5.8 & 3.5 & 3.1 & 6.2 & 3.7 & 3.0 & 3.6 \\
\hline \multicolumn{10}{|c|}{ Summed features ${ }^{\star}$} \\
\hline 2 & 0.9 & 2.7 & - & 0.8 & 2.3 & 2.1 & - & 0.8 & 2.8 \\
\hline 4 & 14.4 & 5.4 & 29.8 & 21.4 & 13.1 & 13.9 & 17.6 & 23.6 & 18.5 \\
\hline 5 & 3.5 & 26.9 & 18.5 & 17.7 & 19.9 & 20.8 & 9.4 & 8.3 & 17.2 \\
\hline \multicolumn{10}{|c|}{ Unknown fatty acids } \\
\hline ECL 13.565 & - & - & - & - & - & 0.5 & 0.8 & - & 0.4 \\
\hline ECL 16.580 & - & - & - & - & - & - & - & - & 0.5 \\
\hline
\end{tabular}

${ }^{*}$ Summed features represent groups of two or more fatty acids that could not be separated by GLC with the MIDI system. Summed feature 2 consists of one or more of iso- $\mathrm{C}_{15: 1} \mathrm{I}$, iso- $\mathrm{C}_{15: 1} \mathrm{H}$ and $\mathrm{C}_{13: 0}$ $3-\mathrm{OH}$, summed feature 4 consists of iso- $\mathrm{C}_{15: 0} \quad 2-\mathrm{OH}$ and/or $\mathrm{C}_{16: 1} \omega 7 c / t$ and summed feature 5 consists of iso- $\mathrm{C}_{17: 1} \mathrm{I}$ and/or anteiso- $\mathrm{C}_{17: 1} \mathrm{~B}$. 
L-arabinose, D- and L-arabitol, cellobiose, dulcitol, erythritol, D-fructose, D- and L-fucose, gentiobiose, gluconate, D-glucose, glycogen, inositol, inulin, 2-ketogluconate, D-lactose, D-lyxose, maltose, D-mannitol, methyl $\alpha$-Dglucopyranoside, melezitose, melibiose, methyl $\alpha$-D-mannopyranoside, methyl $\beta$-D-xylose, raffinose, L-rhamnose, sucrose, salicin, D-sorbitol, L-sorbose, D-tagatose, trehalose, turanose, xylitol and D- and L-xylose (API $50 \mathrm{CH}$ ). Negative for assimilation of caprate, adipate, malate, citrate and phenylacetate (API 20NE). Negative for lysine decarboxylase, ornithine decarboxylase and tryptophan deaminase activities and for production of hydrogen sulfide and indole. Weakly positive for acetoin production (Voges-Proskauer reaction). Acid is not produced from Dglucose, melibiose, amygdalin, L-arabinose, D-mannitol, inositol, D-sorbitol, L-rhamnose or sucrose (API 20E). Positive for arginine dihydrolase, urease and aesculin hydrolysis and negative for glucose acidification (API 20NE). In API ZYM tests, positive results are obtained for acid phosphatase, alkaline phosphatase, cystine arylamidase, esterase lipase (C8), esterase (C4), $\beta$-galactosidase, $\alpha$ glucosidase, leucine arylamidase, naphthol-AS-BI-phosphohydrolase and valine arylamidase, weakly positive results are obtained for $N$-acetyl- $\beta$-glucosaminidase, $\alpha$ galactosidase and $\beta$-glucosidase and negative results are obtained for $\alpha$-chymotrypsin, $\alpha$-fucosidase, $\beta$-glucuronidase, lipase (C14), $\alpha$-mannosidase and trypsin.

The type strain, $\mathrm{PB} 17^{\mathrm{T}}\left(=\mathrm{KCTC} 12607^{\mathrm{T}}=\mathrm{LMG} 24240^{\mathrm{T}}\right)$, was isolated from grass soil in Daejeon, Republic of Korea.

\section{Acknowledgements}

This work was supported by the 21C Frontier Microbial Genomics and Application Center Program, Ministry of Science and Technology (grant MG05-0101-4-0), Republic of Korea. We thank Jean Euzéby for his help with the etymology of the species epithet.

\section{References}

Ausubel, F. M., Brent, R., Kingston, R. E., Moore, D. D., Seidman, J. G., Smith, J. A. \& Struhl, K. (editors) (1987). Current Protocols in Molecular Biology. New York: Wiley.

Benson, D. A., Karsch-Mizrachi, I., Lipman, D. J., Ostell, J. \& Wheeler, D. L. (2005). GenBank. Nucleic Acids Res 33, D34-D38.

Buck, J. D. (1982). Nonstaining (KOH) method for determination of gram reactions of marine bacteria. Appl Environ Microbiol 44, 992-993.

Buczolits, S., Denner, E. B. M., Vybiral, D., Wieser, M., Kämpfer, P. \& Busse, H.-J. (2002). Classification of three airborne bacteria and proposal of Hymenobacter aerophilus sp. nov. Int J Syst Evol Microbiol 52, 445-456.

Buczolits, S., Denner, E. B. M., Kämpfer, P. \& Busse, H.-J. (2006). Proposal of Hymenobacter norwichensis sp. nov., classification of 'Taxeobacter ocellatus', 'Taxeobacter gelupurpurascens' and 'Taxeobacter chitinovorans' as Hymenobacter ocellatus sp. nov., Hymenobacter gelipurpurascens sp. nov. and Hymenobacter chitinivorans sp. nov., respectively, and emended description of the genus Hymenobacter Hirsch et al. 1999. Int J Syst Evol Microbiol 56, 2071-2078.
Cole, J. R., Chai, B., Farris, R. J., Wang, Q., Kulam, S. A., McGarrell, D. M., Garrity, G. M. \& Tiedje, J. M. (2005). The Ribosomal Database Project (RDP-II): sequences and tools for high-throughput rRNA analysis. Nucleic Acids Res 33, D294-D296.

Collins, M. D., Hutson, R. A., Grant, I. R. \& Patterson, M. F. (2000). Phylogenetic characterization of a novel radiation-resistant bacterium from irradiated pork: description of Hymenobacter actinosclerus sp. nov. Int J Syst Evol Microbiol 50, 731-734.

Fautz, E. \& Reichenbach, H. (1980). A simple test for flexirubin-type pigments. FEMS Microbiol Lett 8, 87-91.

Felsenstein, J. (1985). Confidence limits on phylogenies: an approach using the bootstrap. Evolution 39, 783-791.

Garrity, G. M. \& Holt, J. G. (2001). The road map to the Manual. In Bergey's Manual of Systematic Bacteriology, 2nd edn, vol. 1, pp. 119166. Edited by D. R. Boone, R. W. Castenholz \& G. M. Garrity. New York: Springer.

Hall, T. A. (1999). BioEdit: a user-friendly biological sequence alignment editor and analysis program for Windows 95/98/NT. Nucleic Acids Symp Ser 41, 95-98.

Hiraishi, A., Ueda, Y., Ishihara, J. \& Mori, T. (1996). Comparative lipoquinone analysis of influent sewage and activated sludge by highperformance liquid chromatography and photodiode array detection. J Gen Appl Microbiol 42, 457-469.

Hirsch, P., Ludwig, W., Hethke, C., Sittig, M., Hoffmann, B. \& Gallikowski, C. A. (1998). Hymenobacter roseosalivarius gen. nov., sp. nov. from continental Antarctica soils and sandstone: bacteria of the Cytophaga/Flavobacterium/Bacteroides line of phylogenetic descent. Syst Appl Microbiol 21, 374-383.

Kim, M.-K., Im, W.-T., Ohta, H., Lee, M. \& Lee, S.-T. (2005). Sphingopyxis granuli sp. nov., a $\beta$-glucosidase-producing bacterium in the family Sphingomonadaceae in $\alpha-4$ subclass of the Proteobacteria. J Microbiol 43, 152-157.

Kimura, M. (1983). The Neutral Theory of Molecular Evolution. Cambridge: Cambridge University Press.

Kumar, S., Tamura, K. \& Nei, M. (2004). MEGA3: integrated software for molecular evolutionary genetics analysis and sequence alignment. Brief Bioinform 5, 150-163.

Mesbah, M. \& Whitman, W. B. (1989). Measurement of deoxyguanosine/thymidine ratios in complex mixtures by high-performance liquid chromatography for determination of the mole percentage guanine + cytosine of DNA. J Chromatogr 479, 297-306.

Saitou, N. \& Nei, M. (1987). The neighbor-joining method: a new method for reconstructing phylogenetic trees. Mol Biol Evol 4, 406-425.

Sasser, M. (1990). Identification of bacteria by gas chromatography of cellular fatty acids, MIDI Technical Note 101. Newark, DE: MIDI Inc.

Thompson, J. D., Gibson, T. J., Plewniak, F., Jeanmougin, F. \& Higgins, D. G. (1997). The CLUSTAL_X windows interface: flexible strategies for multiple sequence alignment aided by quality analysis tools. Nucleic Acids Res 25, 4876-4882.

Tschech, A. \& Pfennig, N. (1984). Growth yield increase linked to caffeate reduction in Acetobacterium woodii. Arch Microbiol 137, 163-167.

Widdel, F. \& Bak, F. (1992). Gram-negative mesophilic sulfatereducing bacteria. In The Prokaryotes, 2nd edn, pp. 3352-3378. Edited by A. Balows, H. G. Trüper, M. Dworkin, W. Harder \& K. H. Schleifer. New York: Springer.

Widdel, F., Kohring, G. W. \& Mayer, F. (1983). Studies in dissimilatory sulfate-reducing bacteria that decompose fatty acids. III. Characterization of the filamentous gliding Desulfonema limicola gen. nov. sp. nov., and Desulfonema magnum sp. nov. Arch Microbiol 134, 286-294. 